\title{
APLIKASI STANDAR AKUNTANSI KEUANGAN ENTITAS MIKRO KECIL DAN MENENGAH (SAK-EMKM) PADA UMKM DI KECAMATAN TALANG KELAPA KABUPATEN BANYUASIN
}

\begin{abstract}
Junaidi $^{1}$
${ }^{1}$ Universitas Kader Bangsa, Palembang, Indonesia, junaidisumsel@gmail.com

Abstract

This study aims to determine the application of accounting to MSMEs and analyze financial statement reporting using the SAK-EMKM approach. The sample used was 35 MSME food traders in Talang Kelapa District, Banyuasin Regency. The data used are primary data with data collection techniques using questionnaires and interviews. The analysis technique used is quantitative descriptive. The estimation results conclude that the application of accounting to UMKM food traders in Talang Kelapa still uses a simple method. MSMEs have not been able to apply the accounting cycle correctly. Of the 35 food traders who were sampled, there were only 2 traders who had applied accounting standards well. An understanding of the application of accounting standards needs to be socialized intensively to MSME traders in Talang Kelapa District.
\end{abstract}

Keywords: Accounting Cycle, SAK-EMKM, MSMEs

\section{PENDAHULUAN}

Usaha mikro, kecil dan menengah telah berkembang sangat pesat.Setiap tahun perkembangan dan peningkatan jumlah usaha mikro kecil dan menengah (UMKM) semakin meningkat. Badan Pusat Statistik (BPS) menyatakan bahwa pada tahun 2013 UMKM di Indonesia meningkat 2,41\% dari tahun 2012. Peningkatan UMKM tersebut telah membantu perkonomian suatu negara.Oleh karena itu UMKM menjadi salah satu kontribusi yang sangat signifikan dalam PDB dan penyerapan tenaga kerja di Indonesia.

Akuntansi merupakan suatu kegiatan yang mengelolah dan mencatat transaksitransaksi hingga menghasilkan informasi seperti laporan keuangan yang dapat membantu pihak internal dan/atau pihak luar perusahaan dalam mengukur kemampuan ekonomi dalam perusahaan tersebut.Saat ini usaha mikro kecil dan menengah (UMKM) masih melakukan pencatatan transaksi secara sederhana.Salah satu kelemahan UMKM adalah kurangnya pengetahuan dalam akuntansi dan sedikitnya sumber daya manusia yang ahli akuntansi.Hampir semua UMKM belum mengerti standar akuntan untuk menghasilkan informasi seperti laporan keuangan.Mereka hanya mencatat sebagian transaksi yang 
penting secara manual tanpa mengetahui standar akuntansi yang telah ditetapkan.Oleh karena itu, keputusan yang diambil dalam perusahaan tersebut tidak memiliki dasar yang kuat.Serta pada pihak kreditur sering kesulitan dalam menilai kemampuan perusahaan mikro, kecil dan menengah apakah bisa diberi kredit atau tidak.

Pada tahun 2016, Ikatan Akuntansi Indonesia (IAI) telah menerbitkan Standar Akuntansi Keuangan Entitas Mikro Kecil dan Menengah (SAK-EMKM).SAK-EMKM membantu dan mempermudah UMKM dalam menyusun laporan keuangan dengan tepat tanpa harus terjebak dalam kerumitan standar akuntansi yang ada.SAK-EMKM merupakan standar akuntansi keuangan yang lebih sederhana bila dibandingkan dengan SAK-ETAP atau PSAK.

Pedagang makanan di Talang Kelapa ada yang melakukan produksi makanan (aktivitas produksi) tetapi sebagian besar tidak melakukan produksi makanan melainkan membeli makanan (persediaan) dari pihak lain yaitu pemasok. Hal ini dapat dilihat dari merek dan jenis makanan yang mereka jual bukan mereka makanan milik mereka sendiri melainkan merek dan jenis makanan milik orang lain. Pedagang makanan yang memproduksi sendiri melakukan aktivitas membeli bahan baku, memproduksi barang, menjual makanan kepada pihak konsumen, menggaji karyawan, dan membayar beban. Sedangkan pedagang makanan yang tidak memproduksi sendiri melakukan aktivitas membeli persediaan (makanan) dari pemasok, menjual makanan kepada konsumen, menggaji karyawan, dan membayar beban. Namun, transaksi keuangan yang terjadi dalam aktivitas-aktivitas tersebut tidak dicatat dan dilaporkan dengan benar sesuai dengan SAK-EMKM. Oleh karena itu banyak informasi penting dari transaksi tersebut yang tidak dicatat dengan baik dan benar.Sehingga dalam mengambil keputusan, perusahaan hanya memperkirakan tanpa ada dasarnya. Selain itu pada pihak eksternal yang akan memberikan modal atau pinjaman masih meragukan kemampuan ekonomi UMKM tersebut .Hal ini menjadi salah satu faktor yang menyebabkan usaha tidak berkembang.

Berdasarkan latar belakang tersebut,penulis tertarik untuk mengadakan penelitian dengan judul "Aplikasi Standar Akuntansi Keuangan Entitas Mikro Kecil dan Menengah (Sak-Emkm) Pada Usaha Mikro, Kecil, Dan Menengah di Kecamatan Talang Kelapa Kabupaten Banyuasin" . 


\section{METODOLOGI PENELITIAN}

Penelitian ini mengambil 35 UMKM pedagang makanan di Talang Kelapa menggunakan teknik purposive sampling. Teknik purposive sampling adalah proses memilih satuan sampling dengan menggunakan pertimbangan terlebih dahulu untuk terpilih ke dalam sampel.

Ada beberapa pertimbangan yang disajikan sebagai kriteria dalam pemilihan sampel yaitu UMKM yang memiliki kriteria sebagai berikut:

a. Pedagang Makanan;

b. Bangunan/toko baik itu milik sendiri atau sewa;

c. Memiliki karyawan;

d. Memiliki penjualan Rp. 30.000.000 - Rp. 60.000.000 per bulan

Data yang digunakan adalah data primer yang diperoleh melalui kuesioner. Penelitian menggunakan dua instrumen penelitian, yaitu kuesioner sebagai alat bantu dalam pengumpulan data dan Standar Akuntansi Keuangan Entitas Mikro Kecil dan Menengah (SAK-EMKM) sebagai panduan. Data yang telah diambil akan dianalisis dengan analisis deskriptif kuantitatif.

\section{HASIL DAN PEMBAHASAN}

\section{Karakteristik Responden}

Dari hasil penelitian yang dari 35 responden, maka dapat kita ketahui gambaran responden berdasarkan lama usaha dan jumlah karyawan. Berdasarkan lama usaha responden adalah 20\% responden telah mendirikan usahanya selama 1-5 tahun, 26\% responden telah mendirikan usahanya selama 6-10 tahun, 11\% responden telah mendirikan usahanya 11-15 tahun, $6 \%$ responden telah mendirikan usahanya selama 1620 tahun. 14\% responden telah mendirikan usahanya selama 21-25 tahun, 9\% responden yang telah mendirikan usahanya selama 26-30 tahun, dan 14\% responden telah mendirikan usahanya lebih dari 30 tahun.dapat dilihat bahwa sebagian besar responden memiliki lama usaha selama 6-10 tahun.

Berdasarkan jumlah karyawan responden adalah 54\% responden memiliki karyawan sekitar 1-3 orang, 37\% responden memiliki karyawan sekitar 4-6 orang, dan 9\% 
responden memiliki karyawan sekitar 7-10 orang. Maka dapat dilihat bahwa sebagian besar responden memiliki karyawan sekitar 1-3 orang.

\section{Pengetahuan Standar Akuntansi}

Informasi untuk mengetahui pengetahuan UMKM tetang standar akuntansi yaitu data dari kuesioner yang berupa pertanyaan.

1. Peranan Akuntansi dalam kegiatan usaha

Dari pertanyaan "Menurut Anda apakah peranan akuntansi dalam kegiatan usaha itu penting ?"33 UMKM (94\%) menjawab "Ya" yang menyatakan bahwa peranan akuntansi dalam kegiatan usaha itu penting.Sedangkan 2 UMKM (6\%) menjawab "Tidak" yang menyatakan bahwa peranan akuntansi dalam kegiatan usaha tidak penting.Hal ini menunjukkan bahwa sebagian besar UMKM menyadari akuntansi sangat penting dalam kegiatan usaha.

2. Pengetahuan Standar Akuntansi Keuangan Entitas Mikro Kecil dan Menengah (SAKEMKM)

Dari pertanyaan "Apakah anda telah mendengar/mengetahui SAK-EMKM?"0 UMKM (0\%) menjawab "Ya" dan 35 UMKM (100\%) menjawab "Tidak". Hal ini dikarenakan bahwa SAK-EMKM yang baru di terbitkan dan masih dalam proses sosialisasi pada UMKM di Indonesia. Oleh karena itu UMKM pedagang makanan di Talang Kelapatidak pernah mendengar/mengetahui SAK-EMKM.

\section{Siklus Akuntansi}

Informasi untuk mengetahui penerapan akuntansi yang telah dilakukan UMKM yaitu data dari kuesioner yang berupa pertanyaan.

1. Mengumpulkan Bukti Transaksi

Dari pertanyaan “Apakah Anda selalu mengumpulkan seluruh bukti transaksi?”25 UMKM menjawab "Ya" menyatakan bahwa mereka selalu mengumpulkan transaksi, namun sebagian mereka yang mengumpulkan transaksi hanya mengumpulkan faktur pembelian saja dan bukti transaksi disimpan bukan dalam kurun waktu yang lama, misalnya hanya satu/dua minggu.Sedangkan 10 UMKM menjawab "Tidak" menyatakan bahwa mereka tidak mengumpulkan bukti transaksi.Dari hasil penelitian tersebut disimpulkan bahwa UMKM mengumpulkan bukti transaksi walaupun 
sebagian dari mereka tidak selalu mengumpulkan bukti transaksi.Hal ini terjadi karena transaksi dicatat dan bukti transaksi tidak diperlukan lagi.

\section{Mencatat Seluruh Transaksi}

Dari pertanyaan "Apakah Anda membuat catatan dan mencatat seluruh transaksi dalam usaha Anda?" 25UMKM menjawab "Ya" menyatakan bahwa mereka membuat catatan dan mencatat transaksi dalam usaha. Sedangkan 10UMKM lainnya menjawab "Tidak" menyatakan bahwa mereka tidak membuat catatan dan mencatat transaksi dalam usaha. Hal ini terjadi karena mereka telah mengingat transaksitransaksi usaha karena mereka sendiri yang melakukan transaksi-transaksi tersebut.Dari hasil penelitian dapat disimpulkan bahwa sebagian besar UMKM mencatat transaksi yang terjadi dalam usaha mereka.

\section{Membuat Jurnal Akuntansi}

Dari pertanyaan "Apakah pencatatan transaksi dibuat dalam bentuk jurnal akuntansi?"4 UMKM menjawab "Ya" menyatakan bahwa mereka membuat catatan transaksi seperti jurnal akuntansi.4 UMKM tersebut merupakanresponden yang telah mengikuti pelatihan akuntansi. Sedangkan 31UMKM menjawab "Tidak" menyatakan bahwa mereka tidak mencatat transaksi seperti jurnal akuntansi. Hal ini disebabkan karena responden belum mengetahui standar akuntansi dan tidak pernah mengukuti pelatihan akuntansi.Dari hasil penelitian ini menunjukkan bahwa dari 8 UMKM yang telah mengikuti pelatihan akuntansi hanya 2 UMKM yang telah menerapkan salah satu siklus akuntansi, yaitu pencatatan transaksi dalam bentuk jurnal.Dan sebagian besar UMKM masih belum mengerti mencatat sesuai dengan SAK-EMKM.Hal ini dikarenakan mereka belum mengikuti pelatihan akuntansi.

\section{Membuat Buku Besar}

Dari pertanyaan "Apakah Anda membuat buku besar?"23 UMKM menjawab "Ya" menyatakan bahwa mereka membuat buku besar. Sedangkan 12 UMKM menjawab "Tidak" menyatakan bahwa mereka tidak membuat buku besar. Dari hasil penelitian dapat disimpulkan bahwa sebagian besar UMKM membuat buku besar dengan 
memisahkan pencatatan setiap transaksi-transaksi dalam usaha mereka, misalnya buku besar untuk hutang.Namun buku besar yang mereka buat tidak sesuai dengan SAKEMKM.

\section{Laporan Keuangan}

1. Membuat Laporan Laba Rugi

Dari pertanyaan "Apakah Anda membuat laporan laba rugi?"16 UMKM (46\%) menjawab "Ya" menyatakan bahwa UMKM telah membuat laporan laba rugi.Sedangkan 19 UMKM (54\%) menjawab "Tidak" menyatakan bahwa UMKM tidak membuat laporan laba rugi.Dari hasil penelitian ini dapat disimpulkan bahwa sebagian besar UMKM tidak membuat laporan keuangan.Hal ini menunjukkan bahwa laporan laba rugi belum dianggap penting bagi UMKM.Bagi mereka untuk mengetahui keuntungan dapat dilihat dari lebihnya asset (uang) yang mereka miliki pada akhir periode.

2. Membuat Laporan Posisi Keuangan

Dari pertanyaan “Apakah Anda membuat laporan posisi keuangan?”2 UMKM (6\%) menjawab "Ya" menyatakan bahwa responden membuat laporan posisi keuangan, sedangkan 33 UMKM (94\%) menjawab "Tidak" menyatakan bahwa tidak membuat laporan posisi keuangan.Dari hasil penelitian tersebut dapat disimpulkan bahwa dari 8 UMKM yang telah mengikuti pelatihan akuntansi 2 UMKM diantaranya telah membuat dan menyusun laporan posisi keuangan.Sementara sebagian besar UMKM yang tidak mengikuti pelatihan akuntansi masih belum mengerti membuat laporan keuangan dan mereka masih belum menyadari pentingnya laporan posisi keuangan bagi usaha mereka.

3. Pentingnya Laporan Keuangan dalam Pengembangan Usaha

Dari pertanyaan "Apakah laporan keuangan sangat penting dalam pengembangan usaha ?"27 UMKM (77\%) menjawab "Ya" menyatakan bahwa laporan keuangan sangat penting dalam pengembangan usaha.Sedangkan 8 UMKM (23\%) menjawab "Tidak" menyatak bahwa laporangan keuang tidak terlalu penting dalam pengembangan usaha.Dari hasil penelitian ini dapat disimpulkan bahwa sebagian besar UMKM menyadari bahwa laporan keuangan sangat penting dalam 
mengembangkan usaha.Namun mereka masih memiliki keterbatasan untuk membuat laporan keuangan.Hal ini terjadi karena mereka belum mengikuti pelatihan akuntansi. Oleh karena itu, mereka tidak mengetahui cara membuat laporan keuangan yang benar dan sesuai dengan standar akuntansi.

4. Pencatatan dengan komputerisasi

Dari pertanyaan "Apakah Anda mencatat transaksi dan menyusun laporan keuangan dengan koputerisasi ?"3 UMKM (9\%) menjawab "Ya" menyatakan bahwa mereka mencatat transaksi dan membuat laporan keuangan menggunakan komputer Sedangkan 32 UMKM (91\%) menjawab "Tidak" menyatakan bahwa mereka mencatat transaksi dan membuat laporan keuangan masih dengan manual.Dari hasil penelitian ini dapat disimpulkan bahwa sebagian besar UMKM masih menggunakan sistem manual.

\section{Kendala Penyusunan Laporan Keuangan}

Dari 35 responedn 33 UMKM menyadari bahwa akuntansi dalam usaha sangat penting.Namun mereka belum menerapkan akuntansi dalam usaha mereka.Hal ini terjadi karena sebagian besar dari UMKM tidak pernah mengikuti pelatihan akuntansi.77\% UMKM belum pernah mengikuti pelatihan akuntansi.Keterbatasan ilmu akuntansi dan tenaga kerja ahli akuntansi mempengaruhi keputusan pelaku bisnis dalam menerapkan akuntansi yang secara sistematis sesuai dengan prinsip dan standar akuntansi.

\section{Pembahasan}

Berdasarkan hasil penelitian, 94\% responden mengatakan bahwa akuntansi dalam usaha sangat penting.UMKM pedagang makanan di Talang Kelapa telah menyadari bahwa akuntansi dalam kegiatan usaha itu penting.Namun sebagian besar responden masih belum memahami ilmu akuntansi.Hal ini dapat dilihat bahwa hanya 26\% responden yang mengetahui standar-standar akuntansi yang berlaku di Indonesia.

Penerapan akuntansi pada UMKM pedagang makanan di Talang Kelapa masih sangat sederhana.UMKM yang menerapan akuntansi sesuai dengan siklus akuntansi masih sedikit.Pembukuan dalam usaha mereka masih sangat sederhana belum sesuai dengan standar akuntansi yang berlaku.Sama halnya dengan laporan keuangan yang telah dibuat oleh mereka mereka, sebagian besar responden membuat laporan keuangan masih sangat 
sederhana dan belum mendekati SAK-EMKM.Namun ada satu responden yang laporan keuangannya hampir mendekati SAK-EMKM.Dalam laporan posisi keuangan sebagian besar responden hanya melaporkan asset yang mereka miliki walaupun tidak seluruh asset, kewajiban yang mereka miliki (jika ada), dan modal usaha.Dalam laporan laba rugi mereka hanya melaporkan pendapatan dan beban.Namun, tidak seluruh beban yang mereka laporkan di laporan laba rugi. Menurut mereka beban adalah suatu biaya yang harus mereka bayar secara langsung. Oleh karena itu beban penyusutan asset tetap dan beban pajak tidak dilaporkan dalam laporan laba rugi.

Terdapat dua responden malakukan siklus akuntansi dan membuat laporan keuangan yang hampir mendekati SAK-EMKM, yaitu Toko Sulsan Fashion.

\section{KESIMPULAN DAN SARAN}

Dari hasil penellitian dan pembahasan dapat ditarik kesimpulan, yaitu:

1. Penerapan akuntansi pada UMKM pedagang makanan di Talang Kelapa masih sangat sederhana. UMKM masih belum menerapkan siklus akuntansi dengan lengkap. UMKM hanya menerapkan siklus awal akuntansi, yaitu mengumpulkan bukti transaksi, mencatat transaksi. Transaksi-transaksi yang dikumpulkan sebagian besar adalah transaksi pembelian, sedangkan transaksi penjualan tidak dikumpulkan melainkan hanya dicatat. Pencatatan yang dilakukan oleh UMKM masih sangat sederhana dan manual. Pencatatan ini belum sesuai dengan standar akuntansi.

2. Pengetahuan akuntansi yang sangat terbatas pada UMKM pedagang makanan di Talang Kelapa menjadi salah satu faktor dalam penyusunan laporan keuangan. UMKM pedagang makanan di Talang Kelapa tidak mengetahui cara menyusun laporan keuangan yang baik dan benar. Sebagian besar UMKM tidak mebuat laporan keuangan. Namun, ada beberapa UMKM yang membuat laporan keuangan tetapi belum mendekati atau sesuai dengan SAK-EMKM.

\section{Saran}

Berdasarkan kesimpulan dari hasil penelitian, maka penulis akan menyampaikan beberapa saran, sebagai berikut: 
1. Bagi pelaku usaha UMKM pedagang makanan di Talang Kelapa yang belum mengikuti pelatihan akuntansi, harus mengikuti pelatihan akuntansi agar dapat mengetahui dan memahami ilmu akuntansi.

2. Bagi pemerintah sosialisasi tentang SAK-EMKM pada UMKM harus ditingkatkan lagi agar UMKM mengetahui dan menerapkan akuntansi berbasis SAK-EMKM.

\section{REFERENSI}

Alfitri, et al. 2013 Penerapan Standar Akuntansi Keuangan Entitas Tanpa Akuntabilitas Publik (Sak-Etap) Pada Usaha Mikro Kecil Menengah (UMKM) Perajin Mebel Desa Gondangsari Kecamatan Juwiring Kabupaten Klaten, JUPE: Jurnal Pendidikan Ekonomi. Vol 2(2)

Gade, Muhammad. 2005. Teori Akuntansi Cetakan 1. Jakarta: Almahira.

Hutahaean, Jeperson. 2014. Konsep Sistem Akuntansi. Yogyakarta: Deepublish Publisher. Ikatan Akuntansi Publik. 2016. Standar Akuntansi Keuangan Entitas Mikro, Kecil, dan Menengah. Jakarta: IAI.

Reeve James M., dkk. 2009. Pengantar Akuntasi-Adaptasi Indonesia. Jakarta: Salemba Empat.

Tuti, Dwijayanti. 2014. Faktor-Faktor Yang Mempengaruhi Pemahaman Umkm Dalam Menyusunan Laporan Keuangan Berdasarkan SAK-ETAP. The $7^{\text {th }}$ NCFB and Doctoral Qolloquium 2014. pp 157-170.

Repubik Indonesia.1998. Keputusan Presiden Republik Indonesia Pengertian Usaha Kecil. Jakarta: Sekretariat Negara.

Republik Indonesia. 2008. Undang-undang Usaha Mikro, Kecil, dan Menengah. Jakarta: Sekretariat Negara.

Sanusi, Anwar. 2011. Metodologi Penelitian Bisnis. Jakarta: Salemba Empat.

Suharyadi dan Purwanto S.K. 2007. Statistika: Untuk Ekonomi dan Keuangan Modern Edisi 2 Buku 1. Jakarta: Salemba Empat.

Teguh, Muhammad. 2014. Metode Kuantitatif Untuk Analisis Ekonomi dan Bisnis. Jakarta: Rajawali.

Tohar, M. 2000. Membuat Usaha Kecil. Yogyakarta: Kasinus. 